\title{
Association of Veiling with Religious Obligation among University Students
}

\author{
Muhammad Arshad, Muhammad Khalid Irfan, Qamar Zaman, Muhammad Akhtar, \\ Muhammad Asif Shahzad \\ PhD Scholars, The Department of Education, The Islamia University of Bahawalpur, \\ Pakistan \\ E-mail:muhammadkhaildirfan@gmail.com,arshad06@gmail.com
}

Accepted: August 05, 2012 Published: September 22, 2012

Doi:10.5296/ijhrs.v3i1.3124

URL: http://dx.doi.org/10.5296/ijhrs.v3i1.3124

\begin{abstract}
Veiling is considered a religious obligation among Muslim women. With respect to veil there are certain Ayat in the Holy Quran (saying of Almighty Allah) as well as Ahadith (saying of the Holy Prophet SAW) that confirmed veil as a religious obligation for Muslim women. For a long time Muslims ruled Indo-Pak Sub-continent influencing heavily on local society. Role of Sufia is another factor of the religious attitude of the people of the Pakistan. But the slogan of modernization and imitation of the traditions of developed countries is a common issue now day that is spoiling the culture of non developed countries. As Pakistan is a country among those who remained a colony of the British who while leaving the region left behind some cultural elements that have been dominated in the society by the name of modernization and veil is one among these changing cultural aspects. Therefore, this study was designed to see the association of veil with religious obligation among university students in Pakistan. The results of the study revealed that it has mixed trend towards the use of veil among university students in Pakistan.
\end{abstract}

Key words: Veil, culture, religious obligation, the Holy Quran, modernization

\section{INTRODUCTION}

Veiling is considered a religious obligation among Muslim women and certain Ayat in the Holy Quran (saying of Almighty Allah) as well as Ahadith (saying of the Holy Prophet) that confirmed it. But the slogan of modernization and imitation of the developed countries has been spoiling the culture of no-developed countries. Veil in general terms, is something that acts like a curtain in hiding, disguising, or obscuring something else, or separating one thing from another. It is also a part of a nun's headdress covering the sides and back of the head. Currently, it is being used as an alternate for Islamic Hijaab, Jilbab or Parda. Real concept of Islamic Veil is clearly different to that of Nun's dressing. It is not just a dress code but as a 
Muslim it is obligatory (Fard) in Islam for women.

\section{LITERATURE REVIEW}

Allah (Jalla Jallaluhu) and His Beloved Prophet Muhammad has laid great stress on using veil (Hijab, Jilbab or Prda) to a Muslim woman. Thirty first Aayat of Surah Al Nur, says:

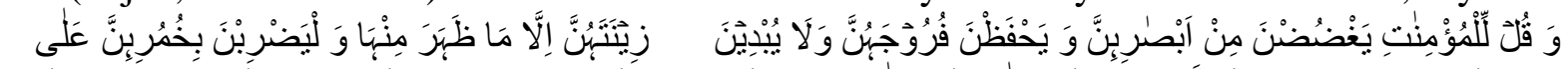

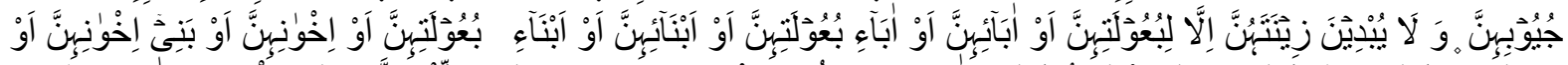

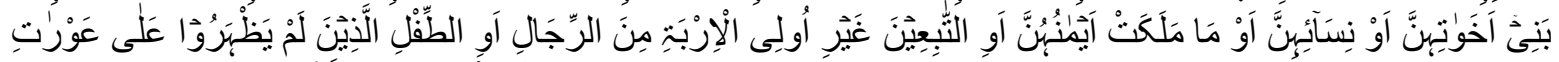

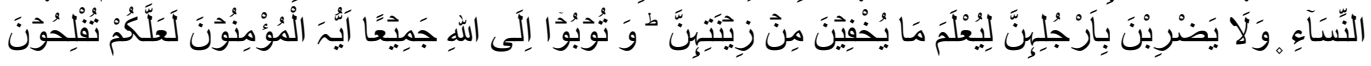

In the initial part of this ayat Allah (Jalla Subhanuhu) says "And tell the believing women to lower their gazes and be modest, and not to display their adornments only that which is apparent, and to draw their veils over their bosoms." Middle part of the Aayat provides us information about "Mahram" in this regard. And the last portion of this Aayat declares that the end result of this good deed is "Falaah" for them (24:31). The concept of "Sitr" is very widely and inclusively used in an Islamic Society. To achieve the goal of a modest and pious society is one of the fundamental purposes of Islam. Veil or Sitre is not obligatory for women only but also includes Believing men. Man and woman are both to play their part. Allah ( Jalla Jalaaluhu ) ordains the male Muslims first.

In Aayat \#30 of the above Surah of the Quran declares:

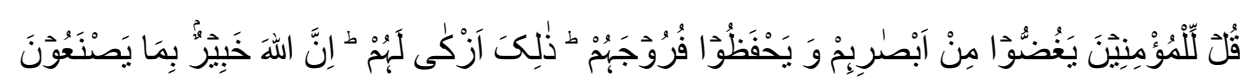

"And tell the believing men to lower their gazes and be modest; it is very much chaste for them. No doubt Allah (Jalla Jalaluhu ) knows their deeds." It means that Allah (Jalla Jalaluhu) has ordered the male Muslims not to see things that Allah has prohibited, do not watch them, and if unintentionally did that do not stare at them or look again (Ibne Katheer).

And the Quraan Al Kareem says:

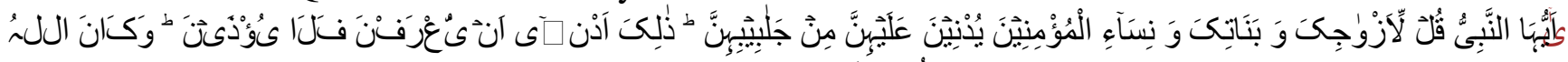

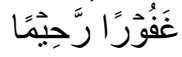

"O; Nabee! Tell thy wives and thy daughters and the women of the believers to draw their cloaks close round them (when they go outside). That will be better, that so they may be recognized and not molested". (33:59).

From above-mentioned Quranic Aayats, it is clear that Allah (Jalla Subhanuhu ) ordered to cover the bodies and strictly rejects and condemns bareness and obscenity. Hazrat Muhammad (صلى الله تعالى علي وآل وسلم ) the beloved Prophet of Allah (Jalla Subhanuhu) says: Aurat is Aurat (a thing to be covered). And when it comes out Satan gazes at her. ( means to gaze at a Na Mahram woman is a Satanic deed). (Tirmazee)

According to the sayings of Muhammad (SAW) Sahih Al-Bukhari Volume 1, Book 4, Hadith \# 148

Narrated by Aisha (Radhiallaahu Ánha): The wives of Rasulullah (Sallallaahu Álayhi 
Wasallam) used to go to Al-Manasi, a vast open place (near Baqia at Medina) to answer the call of nature at night. Hazrat Umar used to say to the Prophet "Let your wives be veiled," but Rasulullah (Sallallaahu Álayhi Wasallam) did not do so. One night Sauda bint Zam'a the wife of the Prophet went out at 'Isha' time and she was a tall lady. Umar addressed her and said, "I have recognized you, O Sauda." He said so, as he desired eagerly that the verses of Al-Hijab (the observing of veils by the Muslim women) may be revealed. So, Allah revealed the verses of "Al-Hijab" (A complete body cover excluding the eyes). The importance of veil is clear from this Hadith; Sahih Al-Bukhari Volume 9, Book 89, Hadith \# 293

Narrated Aisha (Radhiallaahu Ánha) Utba bin Abi Waqqas said to his brother Sa'd bin Abi Waqqas, "The son of the slave girl of Zam'a is from me, so take him into your custody." So in the year of Conquest of Mecca, Sa'd took him and said. (This is) my brother's son whom my brother has asked me to take into my custody." 'Abd bin Zam'a got up before him and said, (He is) my brother and the son of the slave girl of my father, and was born on my father's bed. So they both submitted their case before Rasulullah (Sallallaahu Álayhi Wasallam). Sa'd said, "O Allah's Apostle! This boy is the son of my brother and he entrusted him to me." 'Abd bin Zam'a said, "This boy is my brother and the son of the slave girl of my father, and was born on the bed of my father." Rasulullah (Sallallaahu Álayhi Wasallam) said, "The boy is for you, O 'Abd bin Zam'a!" Then Rasulullah (Sallallaahu Álayhi Wasallam) further said, "The child is for the owner of the bed, and the stone is for the adulterer," Rasulullah (Sallallaahu Álayhi Wasallam) then said to Sauda bint Zam'a, "Veil (screen) yourself before him," when he saw the child's resemblance to 'Utba. The boy did not see her again till he met Allah. This Hadith proves that Rasulullah (Sallallaahu Álayhi Wasallam) in fact ordered the veil to be observed.

\section{The age of Khulfa-i-Rashdeen}

Hazrat Umar advocated the philosophy of the veil as clear that when the hypocrites who attacked women were summoned to explain, he gave justification that they are taken for slaves and God ordered women to change their clothing to distinguish it from that of slaves and to do this by covering themselves with their jilbab (clock). They have to find a way of separating slaves the only ones to be put in a situation where zina was thinkable from free women, the wives of aristocrats and power full men toward whom such approaches were forbidden .Free women "made themselves recognized in order not to be harassed. It was better for them to be recognized. Women veiled their faces and allowed only one eye to be visible." The verse soon descended from heaven -it veiled free women: "O Prophet! Tell the wives and thy daughters and the women of the believers to draw their cloaks close around them (when they go abroad). That will be better, that so they may be recognized and not annoyed." (AL-Ahzaab 33:59)

\section{Veil; Basic right of a Muslim Woman}

There are voices carrying very attractive slogan of Fundamental or Basic Rights, particularly Human Rights: Right to Education, Health, Liberty of Living and Opinion etc. United Nation's Charter gives right to each and every individual on this Globe to enjoy the life style of his own choice irrespective of his/her cast, creed and religion. Every culture has its own 


\section{Al Macrothink}

International Journal of Human Resource Studies

ISSN 2162-3058

2013, Vol. 3, No. 1

dress code that makes it prominent from other cultures or communities (Oloyede, 2010). The requirement of Hijab is not intended to imprison a woman rather it is to protect her from unwanted harm. In the United States alone, one out of three women has been the victim of physical and sexual abuse, (Survey of Women Health, 1999) and a woman is raped every two and a half minutes (National Crime and Victimization Survey, 2006). Because women are vulnerable to exploitation and abuse, Islam advises them to take their protection into their own hands. Although a large number of Western Scholars like King (2009) present it as a violation of human rights and oppression of women by Islam. This interpretation is not according to the Islamic Philosophy of Hijab (Veil) in being aware of it or quotes exceptional cases in this regard. According to Byng (2010) studies shows that it is American media that positioned France, Britain, and the USA as ideologically alike in spite of their different framings of religious freedom even other Western nation despite of their claim of torch bearer of human rights take irrationally and rely on media reports. The reporting supported the interests, values, and hegemony of the West with representations that created the common sense that the Muslim women should not use veil.

While the veil is not a physical practice but is physical and mental also in order to serve as a protective factor against body image issues among women. In fact, if a woman doesn't believe on it, she creates risks of being even more vulnerable. Hijab provides freedom to women from being thought of as sexual object of ill wishes or from being valued for their looks, or body shape rather than their minds and intellect. Hijab liberates women from the need to conform to unrealistic stereotypes and images dictated by the media. Women wearing Hijab have expressed that dressing modestly and covering their hair, minimize sexual harassment on the workplace. The aura of privacy created by Hijab is indicative of the great value on Islam places upon women (Stacey, 2009).

\section{Trends of veil in Pakistani Society}

Pakistan is a multicultural society due to a diverse history of invaders. Some areas of Pakistan have traditionally conservative background like the Tribal Areas and Federally Administered Territory (FATA), some areas of Baluchistan and Khyber Pakhtunkhah. Women living there use traditional "Burqa" that is dominant in that areas.

The dominant types of veil are presented in pictorial form;

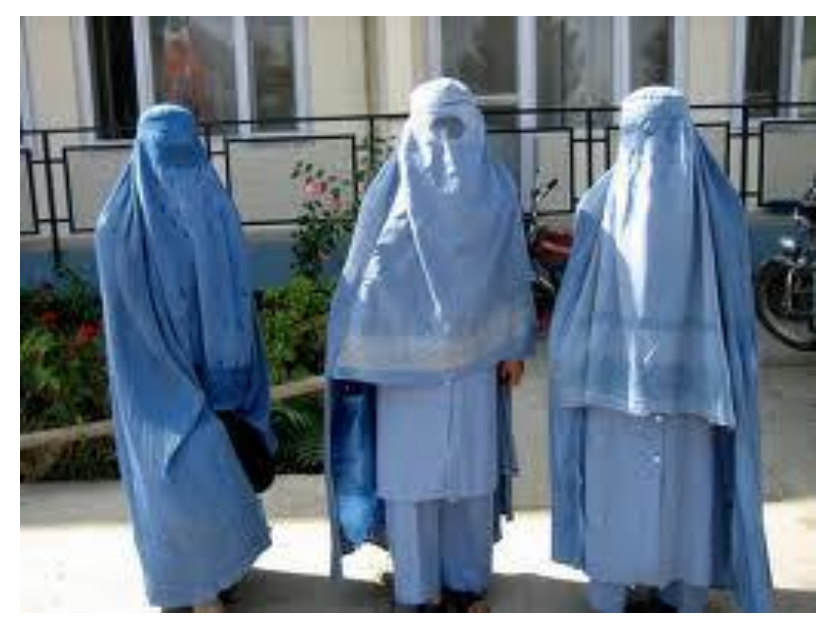


Women from Tribal Areas

Women studying in religious institutes like "Madrassas" and "Jamiaats" wear comparatively Burqa or Gown completely covering their bodies.

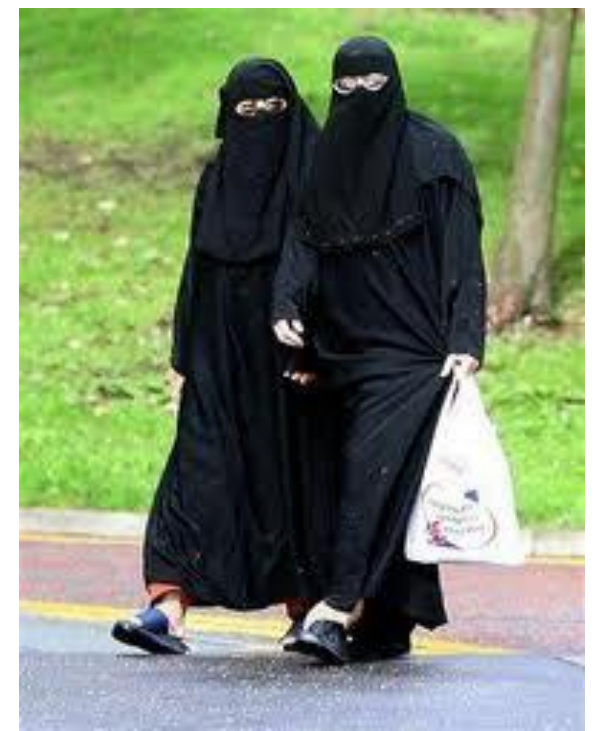

Students from Madrassa

Females studding in Pakistani Universities use different types of Hijaab. Some of them use Niqaab while others use Hijaab or Scarf. But a new trend in university female students is being observed that they use Gown plus Niqaab or Scarf.

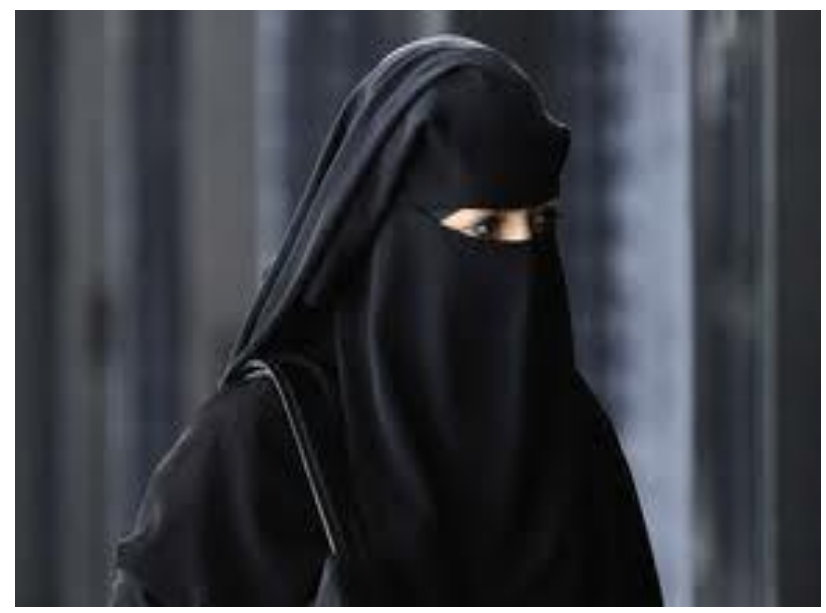

University student with Burqa 


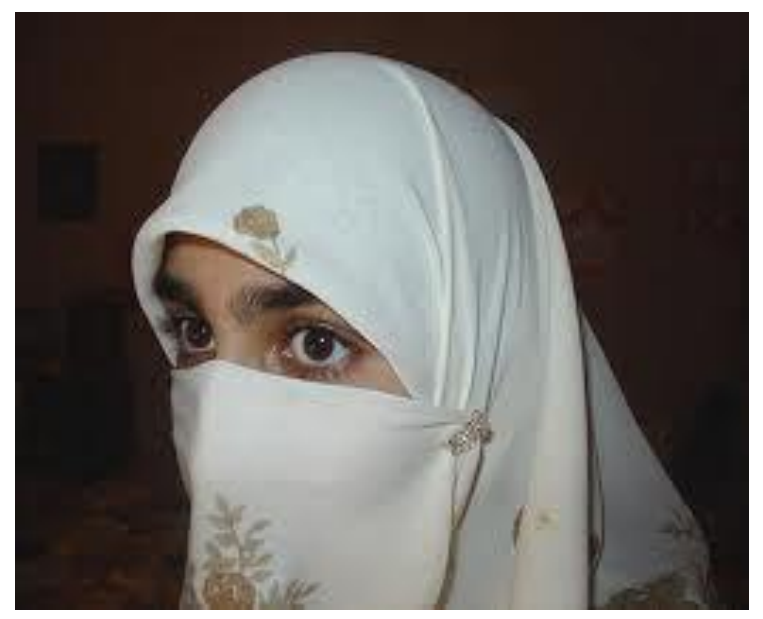

University Student in Hijaab

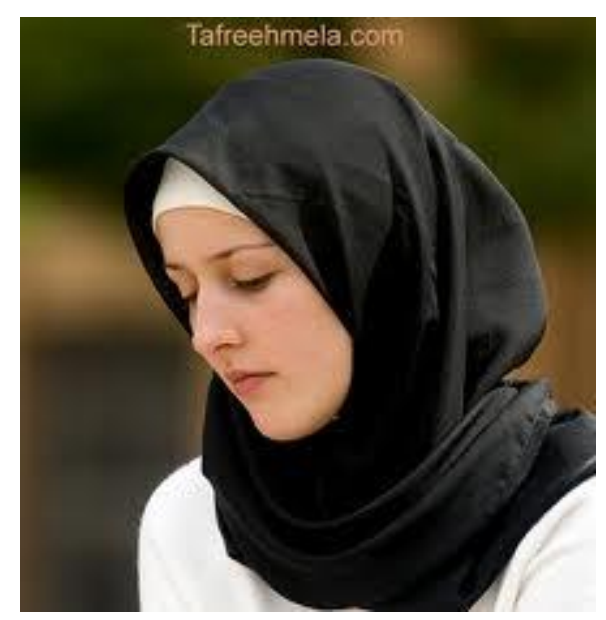

A University Student in Scarf

\section{OBJECTIVES}

This study was conducted to investigate the relationship of veiling with religious obligation among the veiled students in Pakistani Universities. So the objectives of the study were:

- To study student's attitude towards veiling

- To find out relationship between veiling as religious obligation and their practice

- To suggest measures to bridge the gap between students beliefs and practices

\section{METHODOLOGY}

Population of the study was the female university students of The Islamis University of Bahawalpur in lower Punjab and Sargodha University, Sargodha in upper Punjab, using veil. The study delimited to the female students whose use "Burqa" or "Hijaab" as the both of these are considered to be the Islamic veil in Pakistani Society. Simple random sample 
technique was used to select the sample. It was a survey type study and a self-developed questionnaire was used as a research tool to collect data. Three point attitude Likert Scale was used (1-never, 2-ever, 3-always). To make sure reliability and validity of the research tool, it was distributed among teachers, researchers and experts in different departments of the Islamis University of Bahawalpur. According to the suggestions of the experts and researchers it was revised and then administered in the field for data collection. After data collection, the reliability of the tool was found using SPSS software version 17 and Cronbach Alpha (reliability of questionnaire internal consistency) value was found to be 0.935 . The value was strongly significant as the standard value according to Feldmann et al (2007) for the Cronbach Alpha is 0.70 . Then the collected data were analyzed with the help of SPSS using simply Mean, Standard Deviation and Percentage score.

\section{Data Analysis and Interpretation}

The data was collected by personal visit by the researchers. The options vary with respect to the type of the question. Items about the same aspect were sum up and mean value as well as standard deviation while percentage of the items was calculated. Only female university students were respondents in this study either using veil or not using veil. The data was collected randomly and the total respondents were 388; 202 urban and 186 rural. The mean value shows consistency and standard deviation diversity of the respondents' views.

\section{Category of the respondents}

Table-1: Qualification of respondents' parents

\begin{tabular}{l|ll}
\hline Levels & Father \% & Mother \% \\
\hline Illiterate & 5.7 & 20.9 \\
Literate & 12.1 & 25.6 \\
Matric/Intermediate & 29.6 & 28.5 \\
Graduate & 28.9 & 19.6 \\
Higher & 23.7 & 5.4 \\
\hline
\end{tabular}

The number of the respondents with respect their parents' education the is that their father education that is as; materic and intermediate were $29.6 \%$, graduates $28.9 \%$, highly educated $23.7 \%$, literate $12.1 \%$ and only $5.7 \%$ were illiterate. The respondents' belong to the parents where their mother education is materic/intermediate $28.5 \%$, literate $25.6 \%$, illiterate $20.9 \%$, graduate $19.6 \%$ and only $5.4 \%$ have been highly educated.

Table-2: Parents' profession of the respondents

\begin{tabular}{l|clc}
\hline Father's occupation & \multicolumn{3}{l}{ Mother's Occupation } \\
\hline Occupation & $\%$ & Occupation & $\%$ \\
Business & 20.8 & Worker & 15.1 \\
Private job & 6.2 & & \\
Govt job & 42.3 & House-wife & 84.9 \\
Farmer & 13.9 & & \\
\hline
\end{tabular}




\begin{tabular}{l|r|}
\hline Other & 16.8 \\
\hline
\end{tabular}

With respect to parents' occupation of the respondents' their father belongs to Govet job $42.3 \%$, business $20.8 \%$, farmer $13.9 \%$ and are from private job $6.2 \%$ on the other hand mothers' belong to $15.1 \%$ from working persons and $84.9 \%$ working persons.

Table-3: Job status of respondents' parents

\begin{tabular}{c|ccc}
\hline \multicolumn{2}{c|}{ Father's job rank } & \multicolumn{2}{c}{ Mother's job rank } \\
\hline Rank & $\%$ & Rank & $\%$ \\
Worker & 20.70 & Worker & 24.00 \\
Non-gazette & 49.20 & Non-gazette & 52.90 \\
Gazette & 30.10 & Gazette & 23.10 \\
\hline
\end{tabular}

Job status of the parents is as fathers' belong to $49.20 \%$ non-gazzetted, $30.10 \%$ gazette and $20.70 \%$ are from workers' community. While mothers of the respondents are working are $52.90 \%$ non-gazzetted, workers $24.00 \%$ and gazzetted $23.10 \%$.

\section{Over all results with respect to residential areas}

Table-4: Mean value of veiling students with respect to living areas

\begin{tabular}{l|lll}
\hline Area & $N$ & Mean & St.D \\
\hline Urban & 202 & 2.18 & 0.80 \\
Rural & 186 & 2.52 & 1.12 \\
Total & 388 & 2.30 & 0.93 \\
\hline
\end{tabular}

The calculated mean values and standard deviation are presented in the table-1. According to the results mean value of female university students belonging to the urban areas is 2.18 and rural areas is 2.52 (Minimum value $=1$; Maximum value $=3$ ) while standard deviation is 0.80 and 1.12. It means more students belonging to urban areas uses veil as compare to the students from urban areas.

Table-5: Veiling of the students with respect to sect and sub-sects

\begin{tabular}{|c|c|c|c|c|c|}
\hline \multicolumn{3}{|c|}{ Sect wise veiling } & \multicolumn{3}{|c|}{ Sub-sect wise veiling } \\
\hline Sect & Mean & St. $D$ & Sect & Mean & St. $D$ \\
\hline Shia & 2.12 & 0.65 & Deoband & 2.70 & 0.57 \\
\hline Sunni & 2.38 & 1.39 & Brailvi & 1.93 & 0.80 \\
\hline $\begin{array}{c}\text { Did not } \\
\text { mentioned }\end{array}$ & 2.19 & 0.86 & Ahly-i-hadith & 2.46 & 0.80 \\
\hline Total & 2.35 & 0.97 & Did not mentioned & 2.42 & 0.79 \\
\hline & & & Total & 2.35 & 0.74 \\
\hline
\end{tabular}

This table indicates the result in mean and standard deviation values with respect to Muslims sects and sub-sects mostly dominant in Pakistan. According to this table the calculated mean value of sunni sect is 2.38 , shi'a is 2.12 while 2.19 is of those respondents who did not mentioned their sect. with respect to sub-sects the calculated mean value of deoband is 2.70 ; 
Ahly-i-hadith is 2.46 while mean value of those who did not mentioned there sub-sect is 2.42 . It is concluded that more female belonging to sunni sect used veil as compare to shia while with respect to sub-sect deoband female university students used more veil as compare to Ahly-i-hadith and more than brailvi.

Table-6: Sect-wise result

\begin{tabular}{c|cccccccc}
\hline & \multicolumn{2}{|c}{ Sect } & \multicolumn{6}{c}{ Sub-sect } \\
\hline & Sunni & Shia & Did not & Deoband & Brailvi & Ahla-i-Hadith & Other & Did not \\
No & 330 & 26 & 32 & 37 & 40 & 22 & 7 & 282 \\
$\%$ & 85.1 & 6.7 & 8.2 & 9.5 & 10.3 & 5.7 & 1.8 & 72.7 \\
\hline
\end{tabular}

The respondents belongs to $85.1 \%$ sunni and only $6.7 \%$ shia while with respect to sub-sect are deoband $9.50 \%$, brailvi $10.3 \%$, ahaly-i-hadith $5.7 \%$.

\section{Table-7: The knowledge of the Holy Quran}

\begin{tabular}{c|c|cccc}
\hline \multicolumn{2}{c|}{$\begin{array}{c}\text { How many family } \\
\text { members learned holy } \\
\text { Quran }\end{array}$} & \multicolumn{2}{c}{$\begin{array}{c}\text { Family members } \\
\text { memorized the holy } \\
\text { Quran }\end{array}$} & $\begin{array}{c}\text { I learned the holy } \\
\text { Quran }\end{array}$ \\
\hline Option & $\%$ & Option & $\%$ & Option & $\%$ \\
All & 84.3 & Yes & 37.1 & No & 5.9 \\
About half & 14.2 & No & 62.9 & Nazira & 87.1 \\
None & 1.5 & Total & 100 & Hifz & 7.0 \\
\hline
\end{tabular}

The table describes the results of religious knowledge of the family from which the respondents belong $84.3 \%$ replied that all their family members have learned the Holy Quran, $37.1 \%$ have learned The Holy Quran by heart while $87.1 \%$ respondents have learned only Nazira.

Table-8: Cause of recitation of the holy Quran

\begin{tabular}{l|lllllll}
\hline \multicolumn{2}{l}{ Why recite } & Feelings & & Outcomes & & \multicolumn{2}{c}{$\begin{array}{c}\text { Read } \\
\text { Quran in Language }\end{array}$} \\
\hline $\begin{array}{l}\text { Options } \\
\text { Parents }\end{array}$ & $\%$ & Options & $\%$ & Options & $\%$ & Options & $\%$ \\
ask & 10.8 & $\begin{array}{l}\text { Peace } \\
\text { of heart }\end{array}$ & 96.6 & Earn & 29.5 & Arabic & 59.1 \\
$\begin{array}{l}\text { Imitate } \\
\text { others }\end{array}$ & 3.6 & Nothing & 3.4 & $\begin{array}{l}\text { Religious } \\
\text { book }\end{array}$ & 25.6 & Translation & 26.0 \\
$\begin{array}{l}\text { Own } \\
\text { will }\end{array}$ & 85.3 & Total & 100 & $\begin{array}{l}\text { Worldly } \\
\text { wisdom }\end{array}$ & 44.9 & Tafseer & 14.9 \\
\hline
\end{tabular}

The respondents were asked that why they recite the Holy Quran their 85.30\% replied that it is their own will, $96.6 \%$ replied that they felt peace of heart, $44.90 \%$ replied that they read the Holy Quran to get worldly wisdom while $59.1 \%$ replied that they only read the Holy Quran in 
Arabic.

Table-9: Cumulative result

\begin{tabular}{c|cccc}
\hline & $\begin{array}{c}\text { Reciting } \\
\text { Quran at } \\
\text { home }\end{array}$ & $\begin{array}{c}\text { Saying } \\
\text { prayers }\end{array}$ & $\begin{array}{c}\text { Observing } \\
\text { fast }\end{array}$ & $\begin{array}{c}\text { Teacher } \\
\text { reaction }\end{array}$ \\
\hline Mean & 2.50 & 2.50 & 2.72 & 1.86 \\
St.D & 0.79 & 0.43 & 0.46 & 0.50 \\
\hline
\end{tabular}

According to cumulative results majority of the respondents belong from the families where all the members at home recite the Holy Quran and say their prayers, in the same way majority of them say that all their family members observe their fast and a few are agreed that the teachers' reaction towards veil is negative.

Table-10: Association of veiling with religious duties

\begin{tabular}{llllll}
\hline & $\begin{array}{l}\text { Saying } \\
\text { prayers }\end{array}$ & $\begin{array}{l}\text { Observing } \\
\text { fast }\end{array}$ & $\begin{array}{l}\text { Reciting the } \\
\text { Holy Quran }\end{array}$ & $\begin{array}{l}\text { Veiling } \\
\text { culture } \\
\text { society }\end{array}$ & $\begin{array}{l}\text { Veiling } \\
\text { inong } \\
\text { family } \\
\text { members }\end{array}$ \\
$\begin{array}{l}\text { Correlation } \\
\text { value }\end{array}$ & $0.110^{*}$ & $0.114^{*}$ & 0.048 & $0.155^{* *}$ & $0.212^{* *}$ \\
Sig value & 0.030 & 0.024 & 0.343 & 0.002 & 0.000 \\
\hline
\end{tabular}

Pearson's correlation value (2-tailed) significant at 0.05

Pearson's correlation value (2-tailed) significant at $0.01^{\text {** }}$

The table-10 described the association of veil with religious and cultural values. According to this it has significant relation with performing religious duties and veiling culture in the family members as well as among the society.

\section{Conclusions}

The Islamia University is situated in Bahawalpur where religious culture is dominant. It is a belt of the province of the Punjab where Islamic Madrasas are in abundance. So inhabitants of this area have a great affect of religious factor on their life. Majority of the women of this area uses veil so university students also adopt the culture of this area.

The main conclusion of the study is that veil has relation with religion as well as with culture of the family and the society but has more relative to the culture of the family.

Additional conclusions were also drawn from the results that are as;

- More Sunni sect among the respondents uses veil and majority of the Brailvi uses veil.

- Majority of the respondents recite the holy Quran by their own will.

- Majority of them felt peace of heart by reciting the Holy Quran.

- Majority of them read the holy Quran to get worldly wisdom. 
- Majority of them only read the Holy Quran in Arabic.

- According to cumulative results majority of the respondents belong from the families where all the members at home recite the Holy Quran and say their prayers, in the same way majority of them say that all their family members observe their fast and a few are agreed that the teachers' reaction towards veil is negative

\section{SUGGESTIONS}

- Parents should educate provide Islamic education to their children at home.

- Parents should educate their children the Islamic ideology for passing their life.

- Parents should create home environment Islamic.

\section{References}

Alghazali, M. (2008). Ihya ul Uloom ad Deen. Lahore, Pakistn: Progressive Books

Alghazali, M. (2010). Keemia e Sa'adat. Karachi, Pakistan: Maktaba tul Madinah

Al Quraan, Surah Annur, Aayat \#31

Al Quraan, Surah Ahzaab Aayat\#59

Al Quraan, Surah Annur, Aayat \#30

Al-Saji, A. (2010). The racialization of Muslim veils: A philosophical analysis. Philosophy and Social Criticism, 36(8) 875-902

Atasoy, Y. (2006). Governing women's morality : a study of Islamic veiling in Canada. European Journal of Cultural Studies, 9(2): 202-221

Awan, R; Naz, A; Noureen, G; Nasreen A; Aziz, S; \& Hassan, H. (2011). Veiling and Unveiling: Attitudes and Experiences of University Students in the Punjab. International Journal of Social Sciences and Education, 1(4): 355-366

Byng, M. (2010). Symbolically Muslim: Media, Hijab, and the West. Critical Sociology, 36(1) 109-129.

Ibn e Katheer, Imaad ud Deen. Tafseer Ibn e Katheer, Paraa \#18, Surah Annur, Aayat \#30,31

King, A. (2009). Islam, Women and Violence. Feminist Theology, 17(3): 292-328.

Oloyede, I. (2010). Reviving Academic Culture and Etiquette. Paper presented at the $25^{\text {th }}$ AVCNU Conference $19^{\text {th }}-22^{\text {nd }}$ April, 2010, holding at Osun State University Oshogbo.

Sunan al Tirmazi V\#2 pp. 392 Hadith \#1176

Shamsie, M. (2010). Pakistan. Journal of Commonwealth Literature. 45(4): 641-658.
Stacey,
A. (2009).
Why
Muslim
Woman
wear
Veil.

http://www.islamreligion.com/articles/2770/ Retreived on 01-11-2011. 